\title{
PATTERNS AND CAUSES OF MARSUPIAL PATHS IN SUBALPINE TASMANIA
}

\author{
by Emma C. Nichols and Jamie B. Kirkpatrick \\ (with seven text-figures, two plates and one table)
}

\begin{abstract}
Nichols, E.C. \& Kirkpatrick, J.B. 2019 (14:xii) Patterns and causes of marsupial paths in subalpine Tasmania. Papers and Proceedings of the Royal Society of Tasmania 153: 53-60. https://doi.org/10.26749/rstpp.153.53 ISSN 0080-4703. Geography and Spatial Sciences, University of Tasmania, Private Bag 78, GPO, Hobart, Tasmania 7001, Australia (ECN, JBK*). *Author for correspondence. Email: j.kirkpatrick@utas.edu.au

Animal paths can improve connectivity of species, alter vegetation growth, reduce fuel loads and further our knowledge of the behavioural ecology of mammals. Path patterning and the motivations for path creation are not well understood. The present study tested the hypotheses that animals form paths: (i) to efficiently move between palatable patches; (ii) for access to water; (iii) for access to shelter and (iv) to avoid predators. We used high-definition aerial online imagery to map paths in five treeless subalpine environments in Tasmania. Surveys of vegetation and scat counts were conducted at each site. We found that locality influenced wallaby scat density and that macropods and wombats created direct paths to move between areas of palatable vegetation, shelter and water. There was some weak indication of predator avoidance in some of the patterning. However, shelter from cold, strong southwesterly winds is a feasible alternative motivation for the patterns.
\end{abstract}

Key Words: landscape of fear, macropod, path, shelter, wombat.

\section{INTRODUCTION}

Animal paths occur throughout many terrestrial environments and are often a prominent feature of natural landscapes. Animal paths can help identify patterns and processes of movement that can suggest the underlying motivations for path usage (Kays etal. 2015). Understanding path usage can therefore improve our knowledge of the behavioural ecology of a species and of the effects of animal paths on other organisms. Animal paths can influence plant growth (Ferguson et al. 2010), improve connectivity and limit fire spread (Ferguson et al. 2010; Knapp et al. 2016).

Studies of the movements of terrestrial mammals that create paths have predominantly been of large hooved mammals, such as cattle (Ganskopp et al. 2000; Depew 2005), White-tailed Deer (Odocoileus virginianus; Depew 2005), Asiatic Wild Ass (Equus hemionus; Davidson et al. 2013), Wildebeest (Connochaetes taurinus), Tibetan Wild Ass (Equus kiang; Sharma et al. 2004) and Woodland Caribou (Rangifer tarandus caribou; Johnson et al. 2002). Non-hardhooved large herding or pack-forming mammals such as the African Savannah elephants (Loxodonta africana; Loarie et al. 2009) and Grey Wolf (Canis lupus; Huck et al. 2011) also form paths. Davidson et al. (2013) and Sharma et al. (2004) found that wild asses avoid steep slopes. Vegetation density played a significant role in movement decision-making in cattle and White-tailed Deer (Depew 2005), as well as the Asiatic Wild Ass (Davidson et al. 2013). Conserving energy by following paths of least effort is also suggested to be a major influence on cattle movements, particularly when in search of water (Ganskopp et al. 2000). Some of the influences on wildebeest movements are thought to be water access, level of predation risk and sufficient access to food (Martin et al. 2015). The only study that focused on the effects of soft-footed mammal movements found that repetitive movements by wombats, wallabies, pademelons and rats reduced competition for plant species that would otherwise be outcompeted and that paths occupied up to $12 \%$ of the ground within particular vegetation types (Ferguson et al. 2010).

As well as path creation to conserve energy, mammals may create concealed paths to avoid predators in a landscape of fear (Laundré et al. 2001). The landscape of fear results from the non-lethal effects of the fear of predation by prey species. The landscape of fear has been observed in behavioural changes in both elk (Cervus elaphus) and bison (Bison bison) following the reintroduction of wolves (Canis lupus) to Yellowstone National Park (Laundré et al. 2001). This behavioural change showed that prey species adjusted their time spent foraging in a location, as well as avoiding locations associated with higher predation risk (Laundré et al. 2001).

Most of the limited work on animal paths has not mapped the paths themselves. Where paths have been mapped (Ganskopp et al. 2000; Davidson et al. 2013), they have been related to topography rather than vegetation type.

The aim of the present study was to determine patterns and processes in path formation by Australian marsupials in a variety of high-altitude, subalpine environments. We tested the hypothesis that animals form paths to efficiently move between palatable patches, water and shelter. We also determined if there is any evidence that paths form on routes that allow animals to avoid predators. 


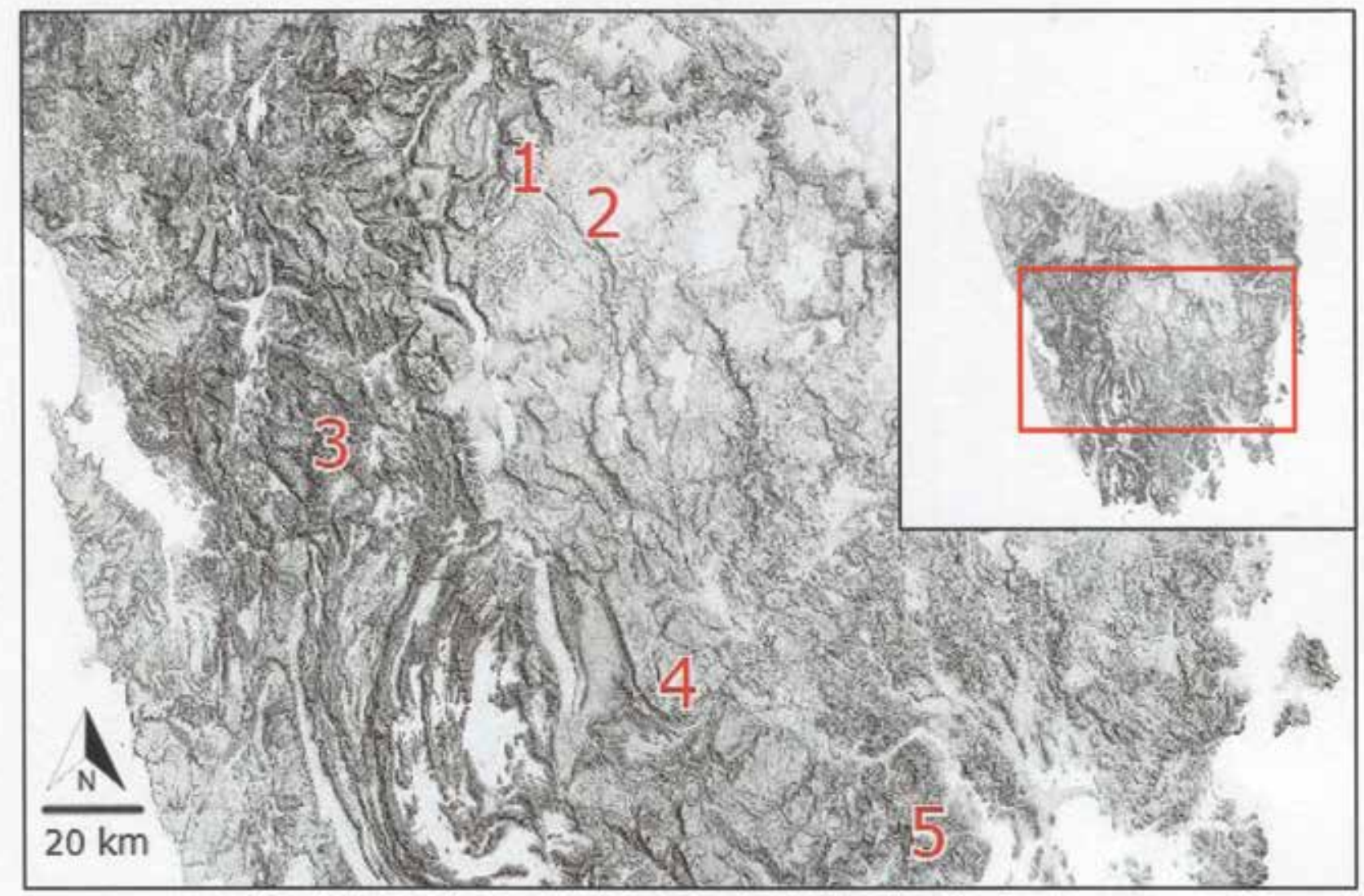

FIG. 1 - Locations of mapping. 1 - Walls of Jerusalem National Park. 2 - Lake Ada, Central Plateau. 3 - Frenchmans Cap. 4 Mount Field East. 5 - Mount Wellington Plateau. Source: The LIST Map (2019).

\section{METHODS}

\section{Study areas}

Five subalpine locations were chosen for surveying because of the availability of high-definition online aerial imagery, which clearly showed paths and vegetation types at each site (fig. 1). The Land Information System Tasmania Map (The LIST Map 2019) was used to identify potential study areas, which were selected to cover a range of path patterns and vegetation types.

The Mount Wellington site (GDA94, MGA55, E517376, $\mathrm{N} 5250586$ ) is on a subalpine plateau at $1140 \mathrm{~m}$. The site rests upon Jurassic dolerite (The LIST Map 2019), and the average annual rainfall is $1000-1500 \mathrm{~mm}$ (Bureau of Meteorology 2016).

Two sites were chosen within the Walls of Jerusalem (E442128, N5370172; E441326, N5370406). The first site was on a north-facing slope where the elevation peaked at $1280 \mathrm{~m}$. The second site was on flat ground, at the mouth of Lake Solomon, at $1260 \mathrm{~m}$. The sites are on Jurassic dolerite (The LIST Map 2019). Annual rainfall averages 2000-3000 mm (BOM 2016).

Lake Ada in the Central Plateau Conservation Area (E455621, N5362641) is at $1140 \mathrm{~m}$. Glacio-fluvial and aeolian material derived from dolerite form rich soils (Pharo \& Kirkpatrick 1994). Annual rainfall averages 1000-1500 mm (BOM 2016).
A site was selected below Mount Field East, in the Mount Field National Park (E471116, N5276984) where the elevation reaches $1190 \mathrm{~m}$ along a flat surface. This site is underlain by Jurassic dolerite (The LIST Map 2019), with average annual rainfall of 2000-3000 mm (BOM 2016).

Frenchmans Cap is an alpine region with consistently cool temperatures all year round. This site is within the Franklin Gordon Rivers National Park (E404295, N5320029). The elevation reaches $1040 \mathrm{~m}$. The surface geology is quartzite (The LIST Map 2019), and the site has an annual average rainfall of 2000-3000 mm (BOM 2016).

\section{Data collection}

Maps of paths and vegetation types were produced at each location from high-resolution aerial photographs from the Land Information System Tasmania Map (The LIST Map 2019) and ground truthing. The mapping scale for Frenchmans Cap and the Walls of Jerusalem was 1:846. All other locations were mapped at 1:1693.

The following vegetation types were discriminated: Astelia alpina sedgeland, Poa grassland, bog, rushland, cushion heath, Orites heath, Gleichenia fernland, Sphagnum bog, Richea acerosa heath, Richea scoparia heath, Empodisma minus rushland, Deschampsia cespitosa tussock grassland, Orites acicularis tall shrubland, Athrotaxis cupressoides (Pencil Pine) scrub, Athrotaxis scrub, and Eucalyptus coccifera scrub. 
Scat surveys were conducted at each location. Typical areas for each of the main vegetation types were selected. Scats were counted in ten $1 \times 1 \mathrm{~m}$ quadrats randomly located within a $10 \times 10 \mathrm{~m}$ sample area. Scats were counted by taxon: macropods (Bennets Wallaby (Macropus rufogriseus) and Tasmanian Pademelon (Thylogale billardierii)), Barenosed Wombat (Vombatus ursinus), Brush-tailed Possum (Trichosurus vulpecula), Spotted-tailed Quoll (Dasyurus maculatus), European Rabbit (Oryctolagus cuniculus) and native rodents (Rattus spp.).

\section{Statistical analysis}

Wallaby scat counts were used for statistical analyses, as wallaby scats were abundant across each site (other taxa were present at only one or two sites). One-way ANOVA was used to assess whether locality had an effect on wallaby scat density, as well as whether there was an effect of vegetation type on wallaby scat density. Each vegetation type was compared to all the others.

The map of the area mapped on Mount Wellington was used to test whether paths were randomly located. The vegetation type at each end of each path was recorded. An equal number of points was distributed randomly across the map and the vegetation type at each of these points was recorded. The significance of the deviation of the path end points from a random distribution was tested using Fishers exact probability test. All analyses used Minitab (version 18.1).

\section{RESULTS}

Wallaby scat density averaged 12.4 scats per $\mathrm{m}^{2}$. Wallaby scat density was lower at Frenchmans Cap $\left(1.5\right.$ per $\left.\mathrm{m}^{2}\right)$ than in the other areas (10.4-18.8 per $\mathrm{m}^{2}$, ANOVA F $=11_{6,208}$, $\mathrm{P}<0.001)$. Wallaby scats were also denser in vegetation with Poa than in vegetation without Poa as a dominant (6.8 per $\mathrm{m}^{2}$ cf. 0.2 per $\mathrm{m}^{2}$, ANOVA $\left.\mathrm{F}=13.71_{1,208}, \mathrm{P}<0.001\right)$. No other vegetation type had higher or lower scat densities than any other vegetation type.

The length of paths through Mount Wellington rushland was $1532 \mathrm{~m}$ (fig. 2). There were $144 \mathrm{~m}$ of paths in vegetation dominated by Poa spp. and Astelia alpina, and $36 \mathrm{~m}$ of paths in grazed rushland. The ends of paths at Mount Wellington were associated with vegetation with Poa spp. ( $\mathrm{p}=0.023)$ and avoided Richea scoparia heath and scrubland $(\mathrm{p}=0.005)$ (table 1$)$. There was some indication that the paths accessed shelter and water, as well as more palatable vegetation, which included an inexplicably heavily grazed patch of Empodisma minus (pl. 1), a species largely ungrazed elsewhere on Mount Wellington.

At the Walls of Jerusalem (figs 3,4) and Lake Ada (fig. 5), paths connected patches of palatable vegetation and these patches with shelter in scrub or woodland, largely passing through alpine heath. In both places, Astelia alpina was grazed when mixed with, or adjacent to, grassland ( $\mathrm{pl}$. 2), which was not the case on Mount Wellington (fig. 2), Mt Field East (fig. 6) or Frenchmans Cap (fig. 7). At the Walls of Jerusalem and Lake Ada, there were paths that ran through concealing vegetation parallel to the most palatable vegetation types (figs 3-5). These tracks are located to the northeast of the palatable vegetation.

At Mt Field East, the Orites heath and the Poa grassland were the main areas of palatable plants. Paths were evident within the heath as well as connecting the heath to sheltering vegetation (fig. 6). Only one small length of path associated with a rock outcrop (fig. 7) was mapped on Frenchmans Cap.

\section{DISCUSSION}

The lower level of scat counts at Frenchmans Cap than elsewhere is likely related to low soil fertility resulting from its quartzite substrate and high rainfall (Kirkpatrick et al. 2014). Highly palatable vegetation with Poa is absent. As with bushwalkers' paths (Whinam \& Chilcott 2003), there appears to be a threshold in numbers before paths become apparent. The importance of grassland in supporting macropods in these subalpine areas is consistent with Statewide data (Kirkpatrick et al. 2011, 2016, Styger et al. 2011).

Macropods and wombats are largely responsible for path formation. They comprise most of the vertebrate animal biomass, as indicated by scat counts (Ferguson et al. 2010). Paths tend to be highly visible within heath and rushland, perhaps indicating that the animals spread out in the more open palatable vegetation types and that any paths are hidden from view in the scrub and woodland where macropods shelter during the day. The paths appear largely to be least-effort routes, similar to the wild ass paths documented by Davidson et al. (2013).

The paths connect grazed areas and also grazed areas with shelter. However, on Mount Wellington, one path ends at permanent water, and some of the paths at Lake Ada and the Walls of Jerusalem could be interpreted as a product of a landscape of fear in that they parallel palatable vegetation but lie within concealing bushes. These two sites have the largest extents of palatable vegetation types and the highest concentrations of scats, and so support many carnivores such as the Tasmanian Devil (Sarcophilus harrisii) and Wedge-tailed Eagle (Aquila audax). Shooting of wallabies roused by dog packs is occasionally allowed near Lake Ada (Department of Primary Industries, Parks, Water and Environment 2016). However, we cannot conclude with certainty that the tracks parallel to the grazed areas are a product of fear (c.f. Laundré et al. 2001), as the grasslands are occasionally immersed and are more exposed to chilling winds than paths among shrub shelter. The location of the parallel tracks to the northeast of palatable vegetation strongly suggests shelter from winds as a motive, given the known importance of strong, icy southwesterly winds in moulding the subalpine vegetation (Morgan et al. 2010).

This present study appears to be the first that maps animal path patterning by Tasmanian herbivorous marsupials. We conclude that animals form paths to efficiently move between palatable patches, water and shelter, but suggest that shelter from the elements rather than from predators may be responsible for paths parallel to palatable vegetation. 
TABLE 1 - Counts of animal paths' beginning and end points at Mount Wellington

\begin{tabular}{lccccccc}
\hline & $\begin{array}{c}\text { Poa } \\
\text { grassland }\end{array}$ & $\begin{array}{c}\text { Eucalyptus } \\
\text { coccifera scrub }\end{array}$ & Rushland & String Bog & Water & $\begin{array}{c}\text { Grazed } \\
\text { rushland }\end{array}$ & $\begin{array}{c}\text { Richea scoparia } \\
\text { heath/scrub }\end{array}$ \\
\hline Path & 9 & 0 & 15 & 0 & 0 & 3 & 0 \\
Non-path $^{1}$ & 3 & 1 & 14 & 2 & 0 & 0 & 7 \\
\hline
\end{tabular}

${ }^{1}$ Non-path shows the random count.
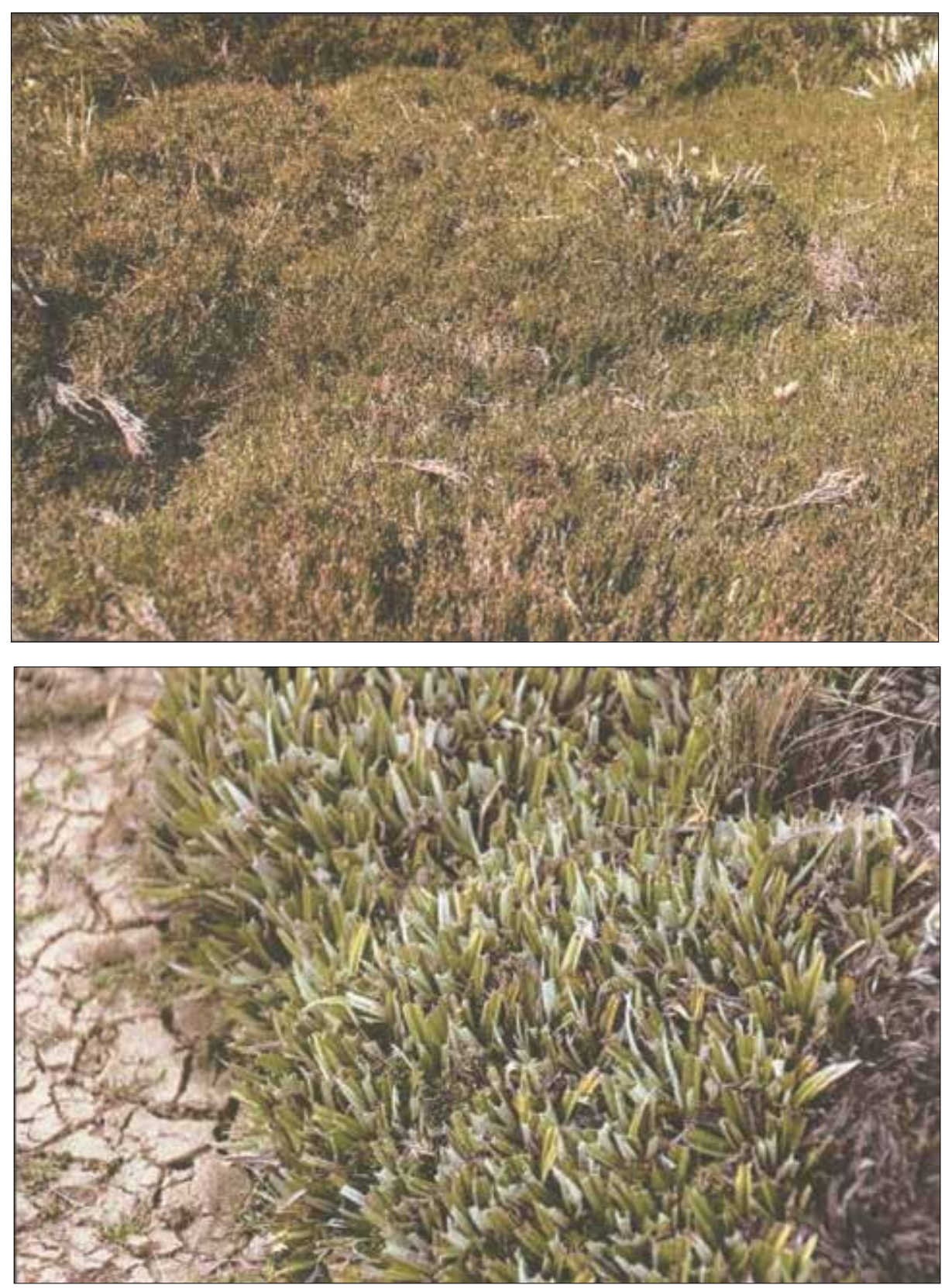

PLATE 1 - Heavily grazed patch of Empodisma minus at Mount Wellington, with ungrazed Astelia alpina.
PLATE 2 - Grazed Astelia alpina at Lake Ada. 


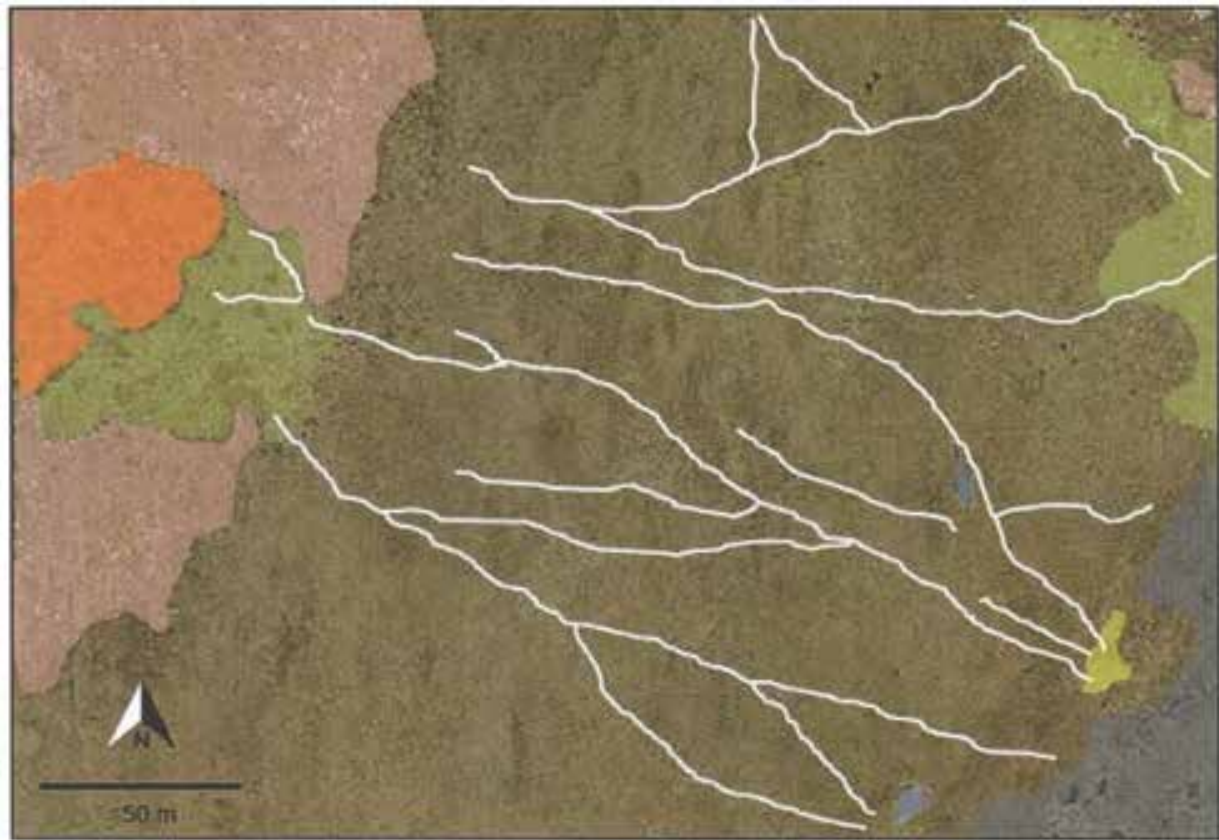

Rushland

Eucalyptus coccifera scrub Heavily grazed rushland Water
Poa/Astelia alpina grassland

Bog

Well-used animal paths

Richea scoparia heath

FIG. 2 - Mount Wellington Plateau (E517482, N5250552). Marsupial paths running through rushland, leading to water sources and palatable vegetation. Source: The LIST Map (2019).
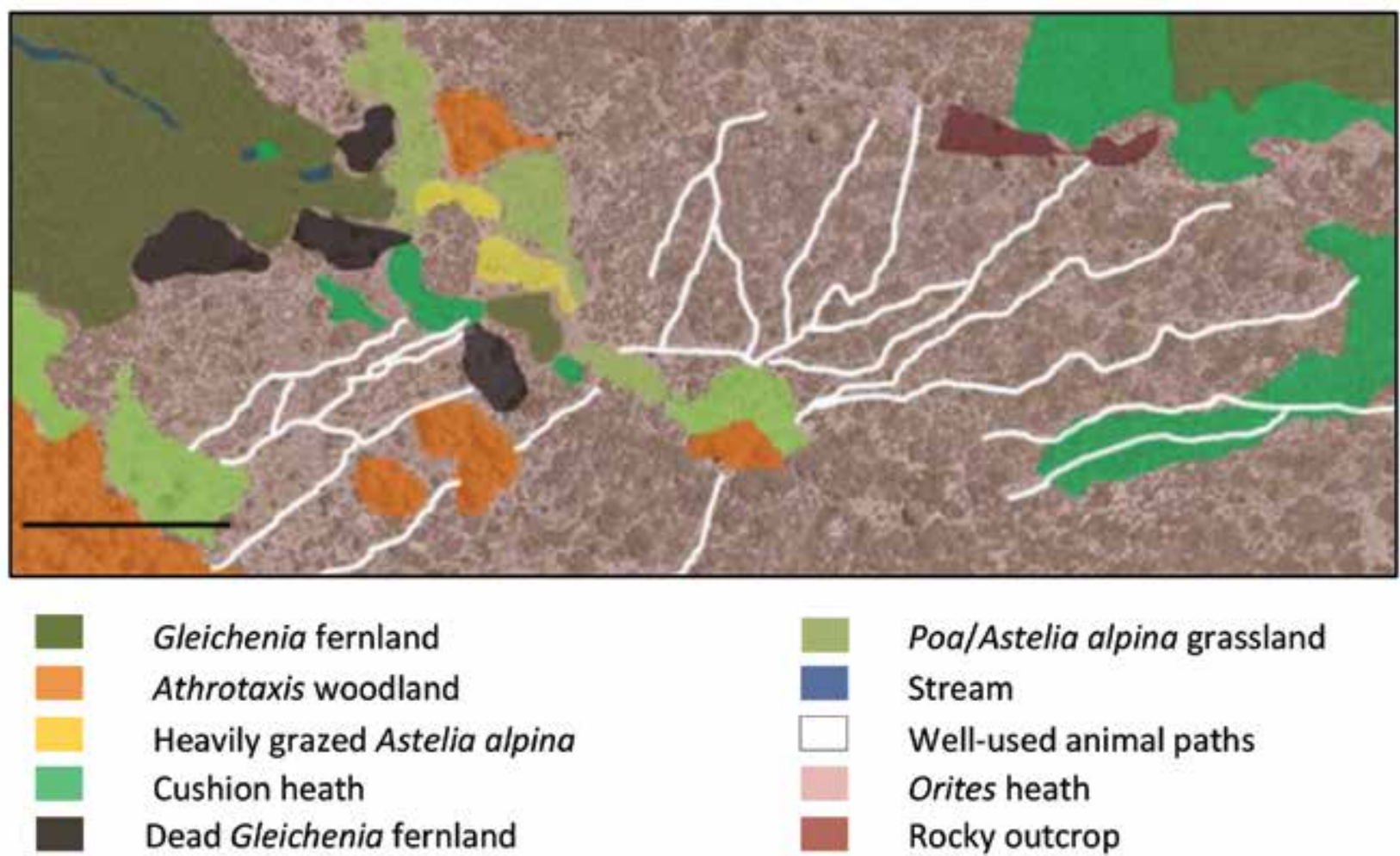

Gleichenia fernland Athrotaxis woodland Heavily grazed Astelia alpina Cushion heath Dead Gleichenia fernland

\section{Poa/Astelia alpina grassland} Stream

\section{Well-used animal paths}

Orites heath

Rocky outcrop

FIG. 3 -Walls of Jerusalem (E442039, N5370177). Dense paths running though Orites heath. Source: The LIST Map (2019). 

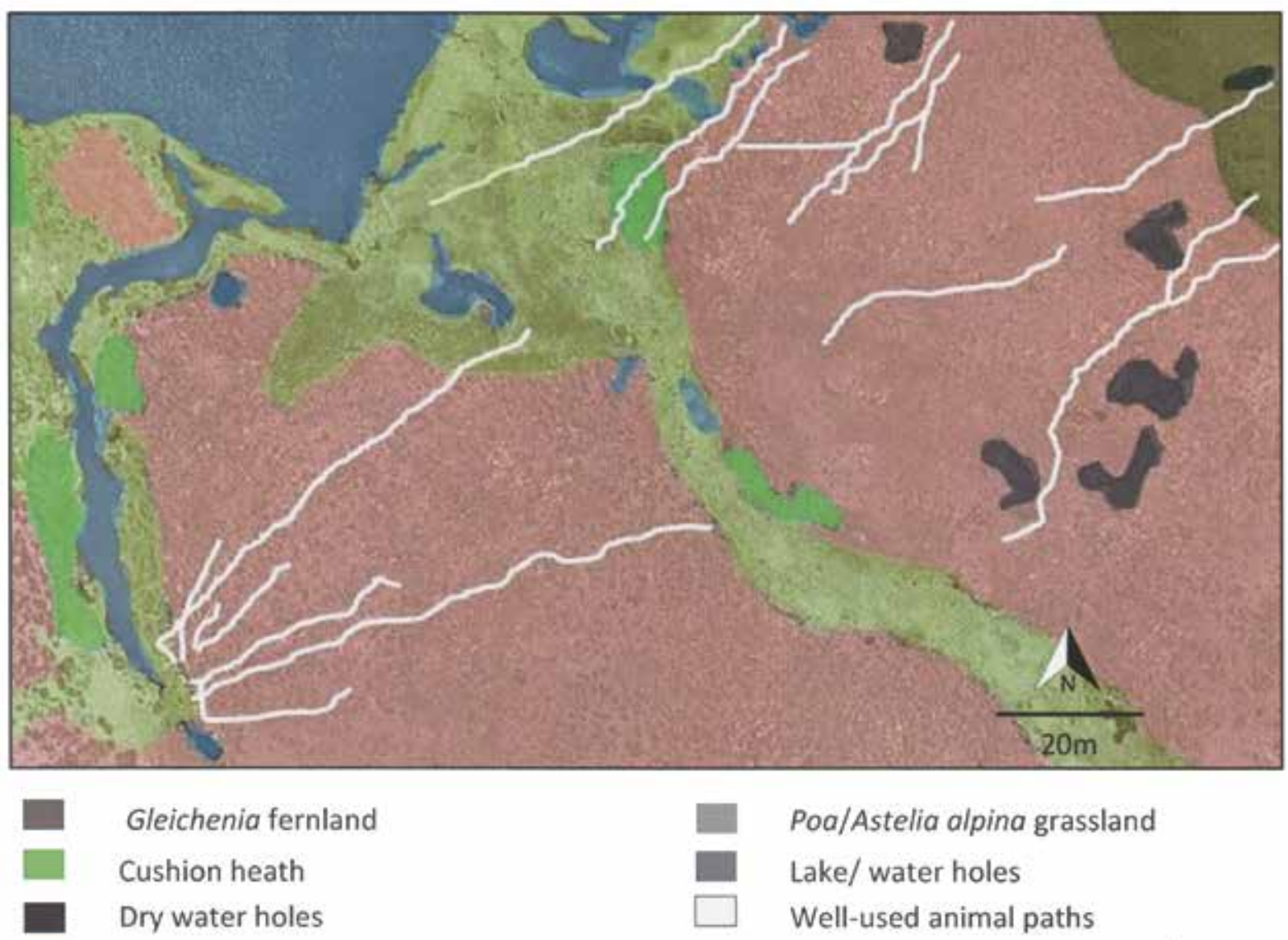

\section{Poa/Astelia alpina grassland}

Lake/ water holes

- Richea scoparia heath

FIG. 4 -At the mouth of Lake Solomon, Walls of Jerusalem National Park (E441326, N5370406). Paths running predominantly west to east. Source: The LIST Map (2019).

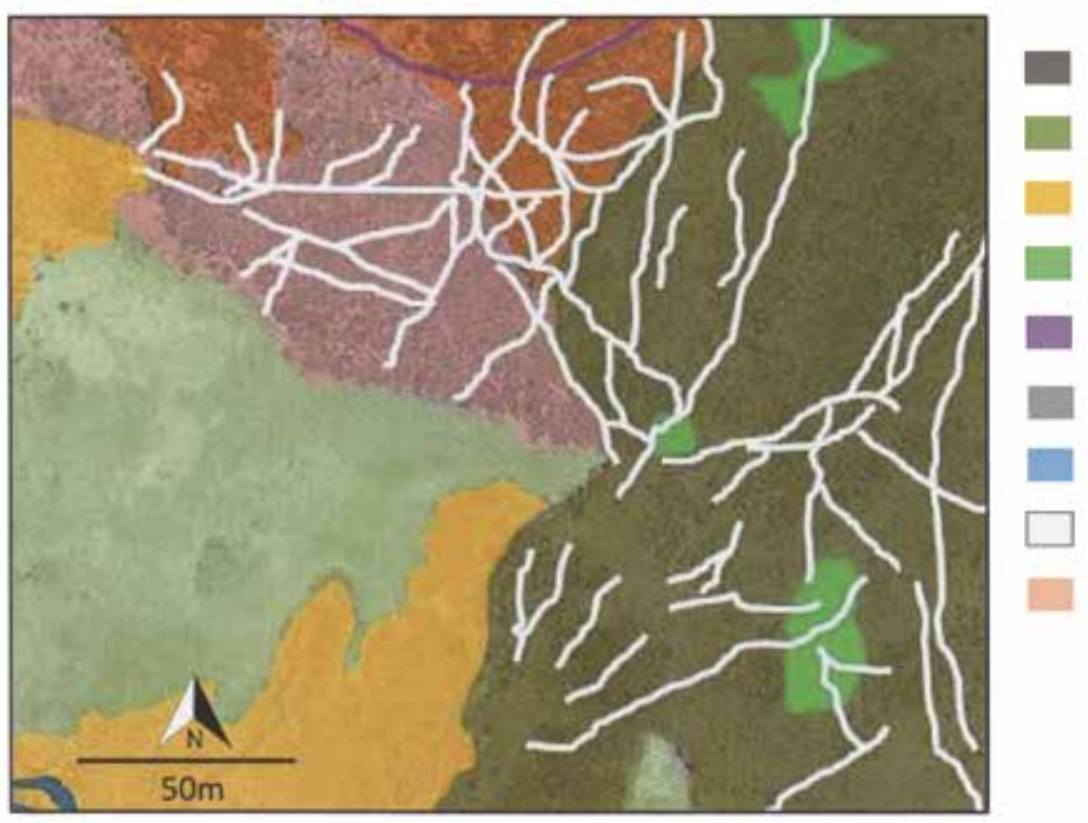

Richea acerosa heath

Orites acicularis tall shrubland

Deschampsia cespitosa grassland

Cushion heath

Old 4WD path

Poa grassland

Stream

Well-used animal paths

Orites heath

FIG. 5 - Lake Ada, central Highlands (E455621, N5362641). Paths running through a variety of dense vegetation types. Source: The LIST Map (2019). 

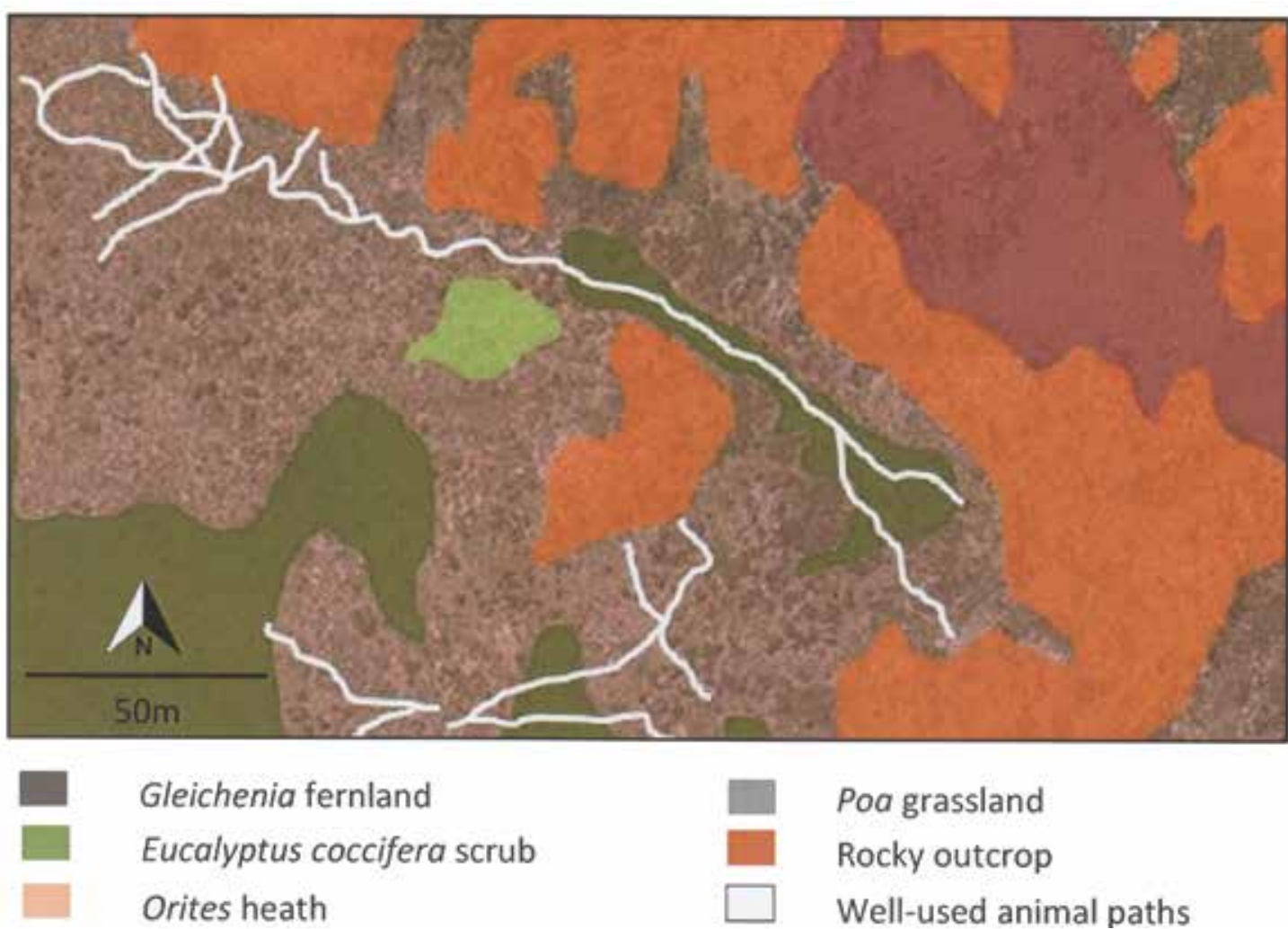

FIG. 6 -Mount Field East (E470468, N5277210). Paths running predominantly east to west at the scrub edge. Source: The LIST Map (2019).

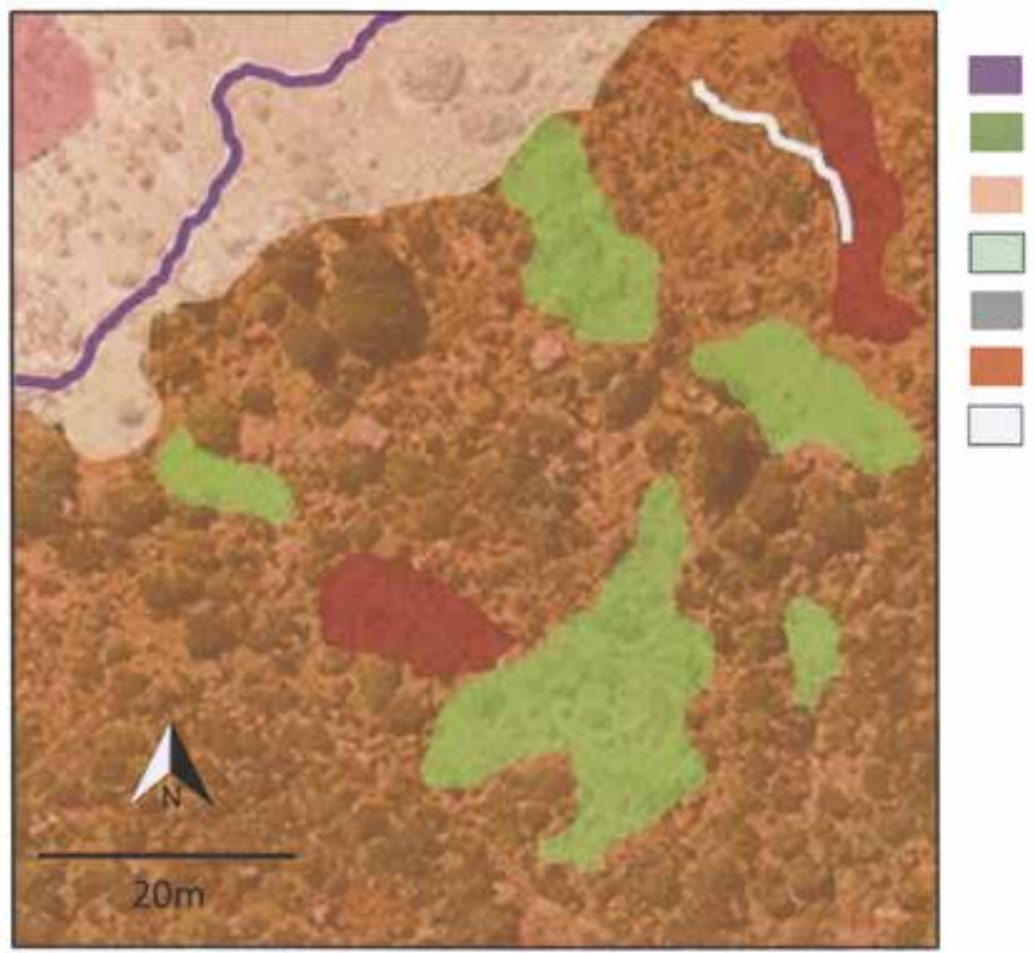

Man-made walking path Athrotaxis woodland Scrub Sphagnum mossland Astelia alpina sedgeland Rocky outcrop

Well-used animal paths

FIG. 7-Frenchmans Cap (E404295, N5320029). One visible path travelling down north-facing slope. Source: The LIST Map (2019). 


\section{REFERENCES}

BOM (Bureau of Meteorology) 2016: Bureau of Meteorology average annual, seasonal and monthly rainfall. http:// www.bom.gov.au/jsp/ncc/climate_averages/rainfall/index. jsp?period=an\&area=ta\#maps (accessed 23 May 2019).

Davidson, A., Carmel, Y. \& Bar-David, S. 2013: Characterizing wild ass pathways using a non-invasive approach: applying least-cost path modelling to guide field surveys and a model selection analysis. Landscape Ecology 28: 1465-1478.

Department of Primary Industries, Parks, Water and Environment 2016: Tasmanian Wilderness World Heritage Management Plan 2016. https://dpipwe.tas.gov. $\mathrm{au} /$ conservation/tasmanian-wilderness-world-heritage-area(twwha)/twwha-management-plan (accessed 30 May 2019).

Depew, J.J. 2005: Habitat selection and movement patterns of cattle and white-tailed deer in a temperate savanna. Doctoral dissertation, Texas A\&M University.

Ferguson, A., Kirkpatrick, J. \& Pharo, E. 2010: Variability in the incidence and characteristics of animal paths in montane vegetation. Plant Ecology \& Diversity 3: 9-17.

Ganskopp, D., Cruz, R. \& Johnson, D.E. 2000: Least-effort pathways? A GIS analysis of livestock trails in rugged terrain. Applied Animal Behaviour Science 68: 179-190.

Huck, M., Jędrzejewski, W., Borowik, T., Jędrzejewska, B., Nowak, S. \& Mysłajek, R.W. 2011: Analyses of least cost paths for determining effects of habitat types on landscape permeability: wolves in Poland. Acta Theriologica 56: 91-101.

Johnson, C.J., Parker, K.L., Heard, D.C. \& Gillingham, M.P. 2002: A multiscale behavioral approach to understanding the movements of woodland caribou. Ecological Applications 12: $1840-1860$.

Kays, R., Crofoot, M.C., Jetz, W. \& Wikelski, M. 2015: Terrestrial animal pathing as an eye on life and planet. Science 348: DOI: $10.1126 /$ science.aaa2478.

Kirkpatrick, J.B., Marsden-Smedley, J.B. \& Leonard, S.W.J. 2011: Influence of grazing and vegetation type on postfire flammability. Journal of Applied Ecology 48: 642-649.

Kirkpatrick, J.B., Green, K., Bridle, K.L. \& Venn, S.E. 2014: Patterns of variation in Australian alpine soils and their relationships to parent material, vegetation formation, climate and topography. Catena 121: 186-194.
Kirkpatrick, J.B., Marsden-Smedley, J.B., di Folco, M-B. \& Leonard, S.W.J. 2016: Influence of grazing and vegetation type on post-fire floristic and lifeform composition in Tasmania. Plant Ecology 217: 57-69.

Knapp, S., Stadler, J., Harpke, A. \& Klotz, S. 2016: Dispersal traits as indicators of vegetation dynamics in long-term old-field succession. Ecological Indicators 65: 44-54.

Laundré, J.W., Hernández, L. \& Altendorf, K.B. 2001: Wolves, elk, and bison: reestablishing the "landscape of fear" in Yellowstone National Park, USA. Canadian Journal of Zoology 79: 1401-1409.

Loarie, S.R., Van Aarde, R.J. \& Pimm, S.L. 2009: Fences and artificial water affect African savannah elephant movement patterns. Biological Conservation 142: 3086-3098.

Martin, J., Benhamou, S., Yoganand, K. \& Owen-Smith, N. 2015: Coping with spatial heterogeneity and temporal variability in resources and risks: adaptive movement behaviour by a large grazing herbivore. PloS ONE 10: e0118461.

Morgan, S., Kirkpatrick, J.B. \& di Folco, M.-B. 2010: Windcontrolled linear patterning and cyclic succession in Tasmanian Sphagnum mires. Journal of Ecology 98: 583-591.

Pharo, E.J. \& Kirkpatrick, J.B. 1994: Vegetation of the alpine sand dunes at Lake Augusta, Tasmania. Australian Journal of Ecology, 19: 319-327.

Sharma, B.D., Clevers, J., De Graaf, R. \& Chapagain, N.R. 2004: Mapping Equus kiang (Tibetan Wild Ass) habitat in Surkhang, Upper Mustang, Nepal. Mountain Research and Development 24: 149-157.

Styger, J.K., Kirkpatrick, J.B., Marsden-Smedley, J.O.N. \& Leonard, S.W.J. 2011: Fire incidence, but not fire size, affects macropod densities. Austral Ecology 36: 679-686.

The LIST Map 2019: The Land Information System Tasmania map, Department of Primary Industries, Parks, Water and Environment (version 1.2.3-21). https://maps.thelist. tas.gov.au/listmap/app/list/map (accessed 25 May 2019).

Whinam, J. \& Chilcott, N.M. 2003: Impacts after four years of experimental trampling on alpine/sub-alpine environments in western Tasmania. Journal of Environmental Management 67: 339-351.

(accepted 6 November 2019) 